\title{
A kinureninrendszer és a stressz
}

\author{
Majláth Zsófia dr. ${ }^{1}$ - Vécsei László dr. ${ }^{1,2}$ \\ 'Szegedi Tudományegyetem, Általános Orvostudományi Kar, Szent-Györgyi Albert Klinikai Centrum, \\ Neurológiai Klinika, Szeged \\ ${ }^{2}$ Magyar Tudományos Akadémia-Szegedi Tudományegyetem (MTA-SZTE) Idegtudományi Kutatócsoport, \\ Szeged
}

\begin{abstract}
A kinureninrendszer a triptofán metabolizmusának fő útja, amelynek során különböző neuroaktív vegyületek keletkeznek. A kinurénsav az excitátoros receptorok endogén antagonistája, amely preklinikai körülmények között neuroprotektívnek bizonyult. A kinureninek kapcsolatba hozhatóak a neuroendokrin szabályozó folyamatokkal is. A stressz számos változást vált ki a kinureninrendszerben, ez a folyamat hozzájárulhat a stresszel kapcsolatos patológiás folyamatokhoz. Az irritábilis bél szindróma és a gyomorfekély kialakulásának jól ismert a kapcsolata a pszichiátriai társbetegségekkel és a stresszel. Kísérletes körülmények között a kinurénsav jótékony hatásúnak bizonyult, mivel csökkentette a bélben a gyulladásos folyamatokat és normalizálta a mikrocirkulációt. Izgalmas feladat a kinureninrendszer és a stressz kapcsolatának pontos megismerése, amely lehetőséget adhat a jövőben új terápiás lehetőségek kifejlesztésére. Orv. Hetil., 2015, 156(35), 1402-1405.
\end{abstract}

Kulcsszavak: stressz, kinureninrendszer, kinurénsav, irritábilis bél szindróma

\section{Stress and the kynurenine pathway}

The kynurenine pathway is the main route of tryptophan degradation which gives rise to several neuroactive metabolites. Kynurenic acid is an endogenous antagonist of excitatory receptors, which proved to be neuroprotective in the preclinical settings. Kynurenines have been implicated in the neuroendocrine regulatory processes. Stress induces several alterations in the kynurenine metabolism and this process may contribute to the development of stress-related pathological processes. Irritable bowel disease and gastric ulcer are well-known disorders which are related to psychiatric comorbidity and stress. In experimental conditions kynurenic acid proved to be beneficial by reducing inflammatory processes and normalizing microcirculation in the bowel. Further investigations are needed to better understand the relations of stress and the kynurenines, with the aim of developing novel therapeutic tools for stress-related pathologies.

Keywords: stress, kynurenine pathway, kynurenic acid, irritable bowel syndrome

Majláth, Zs., Vécsei, L. [Stress and the kynurenine pathway]. Orv. Hetil., 2015, 156(35), 1402-1405.

(Beérkezett: 2015. június 4.; elfogadva: 2015. július 2.)

\section{Rövidítések}

3-OH-KYN = 3-hidroxi-kinurenin; AMPA = 2-amino-3- 5 metil-3-oxo-1,2-oxazol-4-il)propánsav; IDO = indolamin-2,3dioxigenáz; KAT = kinurenin-aminotranszferáz; KMO = kinurenin-3-monooxigenáz; KYNA = kinurénsav; $\mathrm{NMDA}=$ $N$-metil- $D$-aszpartát; QUIN= kvinolinsav

Selye Jánosnak elévülhetetlen szerepe van a stresszelmélet kidolgozásában, ő írta le először a stressz kapcsolatát a hypothalamohypophysealis rendszerrel. Megkülönböztette az úgynevezett negatív stresszt vagy distresszt és a pozitív stressz, vagy más néven eustressz fogalmát. Fontos érdeme volt a stressz-szindróma leírása: mellékvese-hypertrophia, thymusatrophia és gyomorfekély [1, 2]. Krónikus stressz fennállása esetén a szervezet megpróbál alkalmazkodni, és különböző adaptációs mechanizmusok indulnak be. Kóros esetben megjelenhetnek szervkárosodások, mint például kardiológiai komplikációk vagy gyomor-bél rendszeri kórképek, így gyomorfekély vagy irritábilis bél szindróma is. Selye János munkája megalapozta a stresszel kapcsolatos kutatásokat, és bár azóta számos előrelépés történt, ezen a területen még mindig több kérdés nem tisztázott. 
Az utóbbi évek kutatásai alapján felmerül a kinureninrendszer kapcsolata a stresszel. A kinureninrendszer a triptofán metabolizmusának fó útja, mivel a triptofán több mint 95\%-a ezen az anyagcsereúton keresztül alakul át [3]. A kinureninrendszer több neuroaktív vegyületet foglal magába, amelyek részben neurotoxikus, részben neuroprotektív tulajdonságúak lehetnek. Az első meghatározó lépés a triptofán enzimatikus lebontása, amelyet vagy a triptofán-2,3-dioxigenáz, vagy az indolamin-2,3-dioxigenáz (IDO) végez, és ez a lépés határozza meg az anyagcsere-útvonal sebességét. Az útvonal központi intermedier vegyülete az L-kinurenin, amelynél elágazik az anyagcsere. Az L-kinurenint a kinureninaminotranszferáz (KAT) enzimek kinurénsavvá (KYNA) alakítják át, ez az egyetlen ismert endogén glutamátreceptor-antagonista vegyület. Az L-kinurenin másik lehetséges átalakulási útja a kinurenin-3-monooxigenáz (KMO) enzime segítségével 3-hidroxi-kinureninné (3-OH-KYN) történő metabolizmus. A 3-OH-KYN egy többlépcsős folyamat során kvinolinsavvá (QUIN) alakul, majd a folyamat végül a nikotinamid-adenin-dinukleotid szintézisével fejeződik be (1. ábra).

A 3-OH-KYN és a QUIN neurotoxikus hatású molekulák, amelyek szabad gyökök képződését segítik elő, illetve a QUIN az $N$-metil-D-aszpartát (NMDA) típusú glutamátreceptorok agonistája. A KYNA az ionotrop glutamátreceptorok endogén antagonistája, amely képes gátolni az NMDA és a 2-amino-3-(5-metil-3-oxo-1,2oxazol-4-il)propánsav (AMPA) típusú glutamátreceptorokat egyaránt. Emellett az alfa-7-nikotinos acetil-kolinreceptorok nonkompetitív antagonistája, és újabb kutatások szerint a G-protein-kapcsolt GPR35 receptor agonistája is $[4,5,6]$. Az AMPA-receptoron a KYNA hatása dózisfüggő: kis koncentrációban facilitálja, magasabb koncentrációban gátolja azt $[7,8]$. A QUIN neurotoxikus és a KYNA neuroprotektív hatásait számos kísérletes munka bizonyította. A kinureninrendszer szerepét a neurotranszmisziós folyamatok és az idegrendszer-immunrendszer közötti kapcsolat szabályozásában is valószínúsítik $[9,10]$.

A kinureninek szerepét korábban felvetették már a neuroendokrin folyamatokban is. A 3-OH-KYN és a 3-hidroxi-antranilsav kis dózisban képes volt gátolni a leucin indukálta inzulinfelszabadulást patkányban izolált pancreassejteken [11]. Ovarectomizált nőstény patkányokon a QUIN intracisternalis adása képes volt stimulálni a luteinizáló hormon felszabadulását, ezt a hatást a KYNA kivédte [12]. Egy másik vizsgálat leírta, hogy az L-aszpartát csökkenti a corticotropin releasing hormon felszabadulását és fokozza az arginin-vazopresszin vagy más néven antidiuretikus hormon felszabadulását. A KYNA ezeket a hatásokat is képes volt kivédeni in vitro körül-
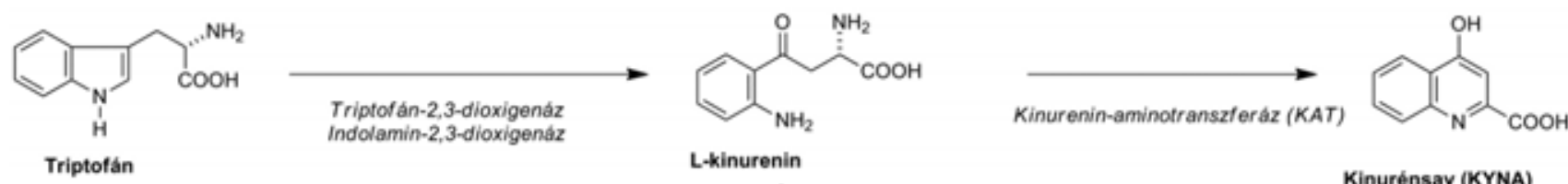

L-kinurenin<smiles>CCOCCOc1cccc(C(=O)C[C@H](N)C(=O)O)c1N</smiles>

3-hidroxi-kinurenin (3-OH-KYN)

Kinurenináz

$\checkmark$<smiles>Cc1cccc(C(=O)O)c1N</smiles>

$\mathrm{OH}$

3-hidroxiantranilsav

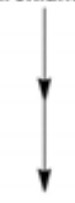<smiles>O=C(O)c1cccnc1C(=O)O</smiles>

Kvinolinsav (QUIN) 
mények között [13]. Ezek az adatok felhívják a figyelmet a kinureninek szabályozószerepére fiziológiás körülmények között. Újabb eredmények pedig felvetették a kinureninrendszer kapcsolatát a metabolikus szindróma kialakulásával is [14]. Az eredmények alapján valószínúsíthető a kinureninrendszer szerepe az immunológiai és neuroendokrin folyamatokban egyaránt, és a stresszre adott adaptációs folyamatokban is.

Állatkísérletek során vizsgálták a stressz hatását egereken, az új környezet szerepelt stressztényezőként, és az eredmények azt igazolták, hogy a stressz következtében az agy különböző területein megemelkedett a triptofán és az L-kinurenin szintje, valamint csökkent a szerotonin/triptofán arány. Ez arra utal, hogy a stressz hatására a triptofán metabolizmusa a kinureninrendszer irányába tolódik el [15]. Később tanulmányozták a ragadozó jelenlétét, mint stressztényezőt, illetve az izoláció hatását is. A ragadozó jelenléte által kiváltott stresszeffektus tartós változásokat idézett elő. Még 4 héttel később is kimutatható volt az egerek agyában a kinureninszint emelkedése, a szerotoninszint csökkenése és a kinurenin/ szerotonin arány emelkedése. A változások elsősorban a hippocampusban, illetve a praefrontalis cortexben voltak jelentősek [16]. Az izoláció következtében szintén jelentôs változások voltak igazolhatóak az állatok agyában: csökkent a kinurenin/szerotonin arány az amygdala és a dorsalis raphe magok területén [17]. Mindezek az eredmények azt igazolják, hogy a stressz jelentős patokémiai változásokat képes elindítani az agyban, amelyek tartósan megváltoztatják az idegrendszer organizációját. Ezekben a folyamatokban jelentös szerepe lehet a kinureninrendszernek, amely befolyásolhatja az immunrendszer múködését és hozzájárulhat a depresszió kialakulásához is.

Egy közelmúltban publikált humán vizsgálat felvetette a kinurénsav mint biomarker szerepét szkizofréniás betegekben. A kísérlet során szkizofréniás betegeket és egészséges kontrollszemélyeket vetettek alá pszichológiai stressznek, és a nyál kinurénsavszintjét határozták meg. Az eredmények azt mutatták, hogy mind a betegek, mind az egészséges kontrollok esetén a saliva kinurénsavszintje magasabb volt azoknál a pácienseknél, akiknek kisebb volt a stressztürő képességük [18].

A pszichológiai stressz stimulálja az IDO enzimet, ezáltal a triptofán szintje csökken, a kinureninrendszer aktiválódik, ezek a változások magyarázhatják a stressz indukálta immunszuppresszív folyamatot és hangulati változásokat egyaránt [19].

A stresszel összefüggésbe hozható betegségek közül az irritábilis bél szindróma, illetve a gyomorfekély előfordulása gyakoriak és súlyos következményekkel járhatnak, a megelőzésük emiatt kiemelkedően fontos. Az irritábilis bél szindróma egyértelmúen szoros kapcsolatot mutat a pszichés státusszal, a neuroendokrin rendszer megváltozott múködésével és a fokozott IDO-aktivitással [20, 21]. A bélmucosában alacsonyabb, míg a plazmában magasabb KYNA-koncentrációt mértek irritábilis bél szind- rómás betegekben, a KYNA-szint szoros korrelációt mutatott a pszichés státusszal is [22]. A fenti eredmények alapján felmerült a KYNA esetleges terápiás hatása bélbetegségekben. Állatkísérletes körülmények között a KYNA-kezelés képes volt csökkenteni a gyomorsavtermelést és javítani mind a stressz indukálta, mind az alkohol indukálta gyomorfekélyeket [23]. Saját vizsgálataink alapján a gyulladásos bélbetegségek állatmodelljében mind a KYNA, mind egy szintetikus származéka, az SZR72 csökkentették a gyulladásos folyamatokat, normalizálták a bél mikrocirkulációját és a bélmotilitást [24, $25,26]$. Egy másik állatkísérletes modellben a stressz hatását újszülött csibéken vizsgálták, a stresszhatást itt az izoláció és a corticotropin releasing hormon injekció jelentette. Intracerebroventricularisan beadott KYNA csökkentette az állatokban a stresszre adott magatartási válaszokat, vagyis a vokalizációt, illetve spontán motoros aktivitást, és alacsonyabb lett a plazma kortikoszteronszintje is [27]. Késóbb sikerült azt is igazolni, hogy a KYNA ezen hatásai elsősorban az NR2A és NR2B alegységeket tartalmazó NMDA-receptorokhoz köthetők [28].

Ezek alapján elmondható, hogy a KYNA és szintetikus származékai ígéretes terápiás lehetőségek lehetnek a stresszel kapcsolatos betegségek, különösen irritábilis bél szindróma esetében.

Anyagi támogatás: Munkánk a Magyar Tudományos Akadémia és Szegedi Tudományegyetem Idegtudományi Kutatócsoportja, a EUROHEADPAIN (FP7-Health 2013-Innovation; Grant No. 602633), valamint a Nemzeti Agykutatási Program KTIA_13_NAP-A-III/9. és KTIA_13_NAP-A-II/17. azonosítószámú projektek támogatásával valósult meg.

Szerzôi munkamegosztás: A cikk elkészítésében a szerzők egyenlő arányban vettek részt, végleges változatát elolvasták és jóváhagyták.

Érdekeltségek: A szerzőknek nincsenek érdekeltségeik.

\section{Irodalom}

[1] Szabo, S.: Hans Selye and the development of the stress concept. Special reference to gastroduodenal ulcerogenesis. Ann. N. Y. Acad. Sci., 1998, 851, 19-27.

[2] Szabo, S., Tache, $\Upsilon$., Somogyi, A.: The legacy of Hans Selye and the origins of stress research: A retrospective 75 years after his landmark brief "Letter" to the Editor of Nature. Stress, 2012, 15(5), $472-478$

[3] Wolf, H.: The effect of hormones and vitamin B6 on urinary excretion of metabolites of the kynurenine pathway. Scand. J. Clin. Lab. Invest. Suppl., 1974, 136, 1-186.

[4] Perkins, M. N., Stone, T. W.: An iontophoretic investigation of the actions of convulsant kynurenines and their interaction with the endogenous excitant quinolinic acid. Brain Res., 1982, 247(1), 184-187.

[5] Hilmas, C., Pereira, E. F., Alkondon, M., et al.: The brain me tabolite kynurenic acid inhibits alpha7 nicotinic receptor activity 
and increases non-alpha7 nicotinic receptor expression: physiopathological implications. J. Neurosci., 2001, 21(19), 74637473.

[6] Wang, J., Simonavicius, N., Wu, X., et al.: Kynurenic acid as a ligand for orphan $G$ protein-coupled receptor GPR35. J. Biol. Chem., 2006, 281(31), 22021-22028.

[7] Prescott, C., Weeks, A. M., Staley, K. J., et al.: Kynurenic acid has a dual action on AMPA receptor responses. Neurosci. Lett., 2006, 402(1-2), 108-112.

[8] Rózsa, E., Robotka, H., Vécsei, L., et al.: The Janus-face kynurenic acid. J. Neural. Transm., 2008, 115(8), 1087-1091.

[9] Németh, H., Toldi, J., Vécsei, L.: Role of kynurenines in the centra and peripheral nervous systems. Curr. Neurovasc. Res., 2005, 2(3), 249-260.

[10] Vécsei, L., Szalárdy, L., Fülöp, F., et al.: Kynurenines in the CNS: recent advances and new questions. Nat. Rev. Drug Discov., 2013, 12(1), 64-82.

[11] Rogers, K. S., Evangelista, S. J.: 3-hydroxykynurenine, 3-hydroxyanthranilic acid, and o-aminophenol inhibit leucine-stimulated insulin release from rat pancreatic islets. Proc. Soc. Exp. Biol. Med., 1985, 178(2), 275-278.

[12] Johnson, M. D., Whetsell, W. O. Jr., Crowley, W. R.: Quinolinic acid stimulates luteinizing hormone secretion in female rats: evidence for involvement of $\mathrm{N}$-methyl-D-aspartate-preferring receptors. Exp. Brain Res., 1985, 59(1), 57-61.

[13] Patchev, V. K., Karalis, K., Chrousos, G. P.: Effects of excitatory amino acid transmitters on hypothalamic corticotropin-releasing hormone (CRH) and arginine-vasopressin (AVP) release in vitro: implications in pituitary-adrenal regulation. Brain Res., 1994, 633(1-2), 312-316.

[14] Oxenkrug, G. F.: Metabolic syndrome, age-associated neuroendocrine disorders, and dysregulation of tryptophan-kynurenine metabolism. Ann. N. Y. Acad. Sci., 2010, 1199, 1-14.

[15] Miura, H., Ozaki, N., Shirokawa, T., et al.: Changes in brain tryptophan metabolism elicited by ageing, social environment, and psychological stress in mice. Stress, 2008, 11(2), 160-169.

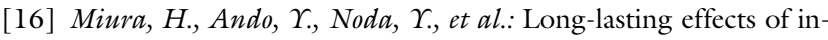
escapable-predator stress on brain tryptophan metabolism and the behavior of juvenile mice. Stress, 2011, 14(3), 262-272.

[17] Miura, H., Shirokawa, T., Isobe, K., et al.: Shifting the balance of brain tryptophan metabolism elicited by isolation housing and systemic administration of lipopolysaccharide in mice. Stress, 2009, 12(3), 206-214.

[18] Chiappelli, J., Pocivavsek, A., Nugent, K. L., et al.: Stress-induced increase in kynurenic acid as a potential biomarker for patients with schizophrenia and distress intolerance. JAMA Psychiatry, 2014, 71(7), 761-768.

[19] Kiank, C., Zeden, J. P., Drude, S., et al.: Psychological stress-induced, IDO1-dependent tryptophan catabolism: implications on immunosuppression in mice and humans. PLoS ONE, 2010, $5(7)$, el1825.

[20] Clarke, G., Fitzgerald, P., Cryan, J. F., et al.: Tryptophan degradation in irritable bowel syndrome: evidence of indoleamine 2,3-dioxygenase activation in a male cohort. BMC Gastroenterol., 2009, 9, 6 .

[21] Patacchioli, F. R., Angelucci, L., Dellerba, G., et al.: Actual stress, psychopathology and salivary cortisol levels in the irritable bowel syndrome (IBS). J. Endocrinol. Invest., 2001, 24(3), 173-177.

[22] Keszthelyi, D., Troost, F. J., Jonkers, D. M., et al.: Alterations in mucosal neuropeptides in patients with irritable bowel syndrome and ulcerative colitis in remission: a role in pain symptom generation? Eur. J. Pain, 2013, 17(9), 1299-1306.

[23] Glavin, G. B., Pinsky, C.: Kynurenic acid attenuates experimental ulcer formation and basal gastric acid secretion in rats. Res. Commun. Chem. Pathol. Pharmacol., 1989, 64(1), 111-119.

[24] Varga, G., Érces, D., Fazekas, B., et al.: N-methyl-D-aspartate receptor antagonism decreases motility and inflammatory activation in the early phase of acute experimental colitis in the rat. Neurogastroenterol. Motil., 2010, 22(2), 217-225, e68.

[25] Érces, D., Varga, G., Fazekas, B., et al.: N-methyl-D-aspartate receptor antagonist therapy suppresses colon motility and inflammatory activation six days after the onset of experimental colitis in rats. Eur. J. Pharmacol., 2012, 691(1-3), 225-234.

[26] Kovacs, T., Varga, G., Erces, D., et al.: Comparative study of novel therapeutic possibilities in animal experimental model of inflammatory bowel disease. [Új terápiás lehetôségek összehasonlító vizsgálata gyulladásos bélbetegség kísérletes modelljén.] Magy. Seb., 2012, 65(4), 191-197. [Hungarian]

[27] Yoshida, J., Tomonaga, S., Ogino, Y., et al.: Intracerebroventricular injection of kynurenic acid attenuates corticotrophin-releasing hormone-augmented stress responses in neonatal chicks. Neuroscience, 2012, 220, 142-148.

[28] Yoshida, J., Shigemura, A., Ogino, Y., et al.: Two receptors are involved in the central functions of kynurenic acid under an acute stress in neonatal chicks. Neuroscience, 2013, 248, 194-200.

(Vécsei László dr., Szeged, Semmelweis u. 6., 6725 e-mail: vecsei.laszlo@med.u-szeged.hu) 